\title{
Investigation of different ways of activation of fly ash-cement mixtures
}

\author{
Part 1. Chemical activation by $\mathrm{Na}_{2} \mathrm{SO}_{4}$ and $\mathrm{Ca}(\mathrm{OH})_{2}$
}

\author{
Iwona Wilińska ${ }^{1}$ (1) $\cdot$ Barbara Pacewska $^{1} \cdot$ Andrzej Ostrowski $^{2}$
}

Received: 15 November 2018/ Accepted: 10 June 2019/Published online: 28 June 2019

(c) The Author(s) 2019

\begin{abstract}
Cement industry emits large amount of $\mathrm{CO}_{2}$. One of the ways to reduce this emission is to use cement replacements, such as fly ash, in binding mixtures. Blends containing fly ash exhibit different properties compared to typical portland cement. In the case of very high amount of fly ash used as substitute of cement, setting and hardening are elongated, and early compressive strength and also often ultimate strength are reduced. Thus, such blends require activation. The aim of the work was to clarify the influence of chemical activators $\left(\mathrm{Ca}(\mathrm{OH})_{2}\right.$ and $\mathrm{Na}_{2} \mathrm{SO}_{4}$ used together) on hydration/activation of fly ash-cement mixtures containing about $80 \%$ of fly ash. Activated mixtures containing inert filler instead of fly ash or cement were also investigated to better understand the influence of chemical activators on each component of the blend. The research included early hydration periods $(3$ and $24 \mathrm{~h}$ ) and subsequent days (till 90th day of hydration). Several methods were used: calorimetry, TG/DTG, FTIR, X-ray diffraction and SEM microscopy.
\end{abstract}

Keywords Fly ash $\cdot$ Cement $\cdot$ Activation $\cdot$ Hydration $\cdot$ Calorimetry $\cdot$ TG/DTG

\section{Introduction}

It is well known that cement industry emits large amount of $\mathrm{CO}_{2}$, mainly as an effect of decarbonation of limestone $[1,2]$. One of the ways to reduce this $\mathrm{CO}_{2}$ emission is the use of cement replacements because of which the demand for portland cement clinker should be lower. Commonly used cements containing fly ash, slag, pozzolans and other components are commercially available [3]. Nowadays, binding "green" mixtures containing ecologically friendly non-clinker components arouse interest and they are the subject of research works, e.g., [4-9]. Some industry byproducts can be used for this purpose. Thus, additional

Iwona Wilińska

Iwona.Wilinska@pw.edu.pl

1 Faculty of Civil Engineering, Mechanics and Petrochemistry, Institute of Chemistry, Warsaw University of Technology, 17 Łukasiewicza St., 09-400 Płock, Poland

2 Faculty of Chemistry, Warsaw University of Technology, 3 Noakowskiego St., 00-664 Warsaw, Poland ecological benefit can be obtained resulting in utilization of these materials.

The amount of fly ash used as replacement of cement usually does not exceed $35 \%$. However, composites containing much higher quantity of fly ash in the binding material arouse interest $[8,10-15]$. Portland cement in lowcement mixtures acts as hydraulic component and activator for fly ash. However, in the case of very high amount of conventional fly ash (70 mass\% and more) and small amount of cement, the properties of early and final hardened composite are rather not satisfactory. It happens because conventional fly ash contains very low amount of calcium compounds and, for this reason, it cannot harden in the presence of water. Such kind of fly ash exhibits pozzolanic properties. It means that active forms of silica and alumina from fly ash can react with $\mathrm{Ca}(\mathrm{OH})_{2}$ in the presence of water. $\mathrm{Ca}(\mathrm{OH})_{2}$ is generated from hydration of cement, in the discussed case. Products of pozzolanic reaction are similar to those that are formed during portland cement hydration [16]. However, in the case of very high volume fly ash (VHVFA) blends, the amount of cement may be insufficient to fully 
develop fly ash activity and to obtain the required properties of the final material. In such case, setting and hardening are extended, and early compressive strength and often also ultimate strength are significantly reduced. This limits the applicability of the material.

There are several methods to activate the system and to enhance its properties [17]. Recently, using some inorganic salts (sulfates or carbonates, e.g., $\mathrm{Na}_{2} \mathrm{SO}_{4}, \mathrm{Na}_{2} \mathrm{CO}_{3}$ ) as chemical activators was proposed [10, 12-15, 18]. Their impact on fly ash grains consists of increasing $\mathrm{pH}$ of reaction environment. It happens because these compounds can react with $\mathrm{Ca}(\mathrm{OH})_{2}$ arising in cement hydration. Solid products of the reaction are precipitated $\left(\mathrm{CaSO}_{4}\right.$ or $\mathrm{CaCO}_{3}$ depending on the kind of activator) and alkaline hydroxide (e.g., $\mathrm{NaOH}$ in the case of sodium salts) is formed. In this way, $\mathrm{pH}$ increases and aluminosilicate fly ash grains can faster dissolve and react. $\mathrm{Na}_{2} \mathrm{SO}_{4}$ is often proposed as chemical activator for VHVFA mixtures, and discussions about mechanism of its action can be found in the literature $[10,12,14]$. Other chemical compounds, including organic salts [13], were also investigated.

Results of our previous research show that some activating effect for VHVFA pastes can be also observed in the case of exchange of small amount of fly ash by more active aluminosilicate pozzolanic material [19]. Influence of selected chemical activators on pozzolanic and hydraulic activities of fly ash [20] and on cement pastes containing typical (30\%) [21] and higher [22] amount of fly ash was also presented.

Results of preliminary investigation of early hydration of fly ash-cement mixtures, recently published by us $[17,23]$, show that it is possible to activate them by mechanical or chemical way. Interesting results were obtained in the case of combined mechanical and chemical activation based on grinding together all dry components, i.e., fly ash, portland cement, $\mathrm{Ca}(\mathrm{OH})_{2}$ and $\mathrm{Na}_{2} \mathrm{SO}_{4}$ $[17,23]$. All this encouraged us to take more exhaustive research on the mechanism of chemical-mechanical activation of VHVFA mixtures. For better understanding of processes of this combined activation, research on the chemical activation (no milling process) and mechanical activation alone (without additional chemical activators) was also undertaken. Such studies are important, taking into account that hydration/activation processes are long term and formed products influence properties of the materials. Moreover, recognition of these processes can be useful in modifying and developing new activation procedures to enhance properties of fly ash-cement blends.

This work is the first part of the series of publications relating to investigation of the proposed different ways of activation of VHVFA mixtures. The aim of this research was to clarify the influence of chemical activators $\left(\mathrm{Ca}(\mathrm{OH})_{2}\right.$ and $\mathrm{Na}_{2} \mathrm{SO}_{4}$ ) on hydration/activation of fly ash-cement mixtures, including products formed on different stages of the process and microstructure of hardened material. $\mathrm{Na}_{2} \mathrm{SO}_{4}$ was used as known accelerator of cement hardening, providing: increase in $\mathrm{pH}$ (as a result of reaction with $\mathrm{Ca}(\mathrm{OH})_{2}$ ), better solubility of fly ash grains, increase in pozzolanic reactivity as well as additional amount of sulfate for further reactions. $\mathrm{Ca}(\mathrm{OH})_{2}$ was proposed as additional component of the mixture to make $\mathrm{Ca}^{2+}$ available earlier for activating reaction. Moreover, excess of $\mathrm{Ca}(\mathrm{OH})_{2}$ can react in pozzolanic reaction in further periods. Pozzolanic activity of fly ash can be developed more, and additional amount of binding phases, such as $\mathrm{C}-\mathrm{S}-\mathrm{H}$ and $\mathrm{C}-\mathrm{A}-\mathrm{S}-\mathrm{H},{ }^{1}$ can be formed. Thus, enhancement of properties of fly ash-cement composites can be expected.

Activated mixtures containing inert filler instead of fly ash or cement were also investigated in this work to better understand the influence of chemical activators on each component of VHVFA blend.

\section{Materials and methods}

Commercially available portland cement CEM I 32,5R and fly ash from conventional pulverized combustion of hard coal in energy industry were used. Average oxide composition (main components) of fly ash is presented in Fig. 1. Size of fly ash grains does not exceed $345 \mu \mathrm{m}$, dimensions of $90 \%$ of grains are below $150 \mu \mathrm{m}$, and mean grain diameter equals $64 \mu \mathrm{m}$. Grains are mostly spherically shaped.

Blend containing 80 mass $\%$ of fly ash (FA) and 20 mass $\%$ of portland cement (PC) was made. Chemical reagents, $\mathrm{Na}_{2}$ $\mathrm{SO}_{4}$ and $\mathrm{Ca}(\mathrm{OH})_{2}$, of analytical purity were used as activators. They were introduced as dry powders into dry fly ash-cement mix in amount 4 and $10 \%$, respectively, calculated with reference to fly ash + cement mass. TG/DTG curves, IR spectra and X-ray diffraction pattern for such dry mixture ( 0 day of hydration) are presented in Figs. 2-4. Mixtures containing fine sand (S), as inert component, instead of FA or PC were also made. Distilled water was added into dry components in an amount providing water/binder $=0.5$. Compositions of samples are presented in Table 1.

Pastes were closed in small polyethylene bags immediately after mixing, and then they were stored at room temperature. After 3 h, 24 h, 7, 28 and 90 days of hydration, the samples were removed from the bags. They were crushed, and hydration processes were stopped using acetone [19]. The samples were investigated by TG/DTG, FTIR and XRD. SEM observations were carried out on small pieces of pastes. Samples subjected to calorimetric measurements were hydrated in calorimeter at $25{ }^{\circ} \mathrm{C}$.

The following research methods, apparatus and conditions were used:

\footnotetext{
${ }^{1}$ Abbreviations used in cement chemistry: $\mathrm{C}-\mathrm{CaO}, \mathrm{S}-\mathrm{SiO}_{2}, \mathrm{~A}-\mathrm{Al}_{2} \mathrm{O}_{3}$, $\mathrm{H}-\mathrm{H}_{2} \mathrm{O}$.
} 


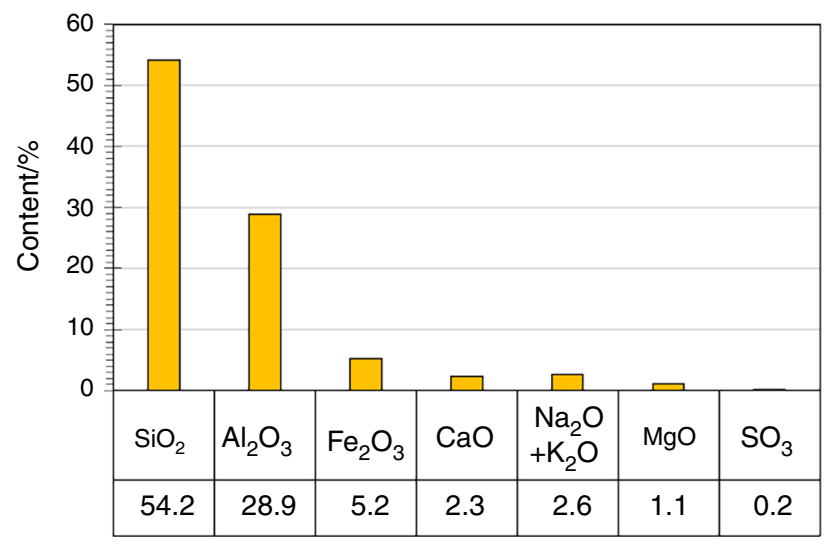

Fig. 1 Average oxide composition of fly ash

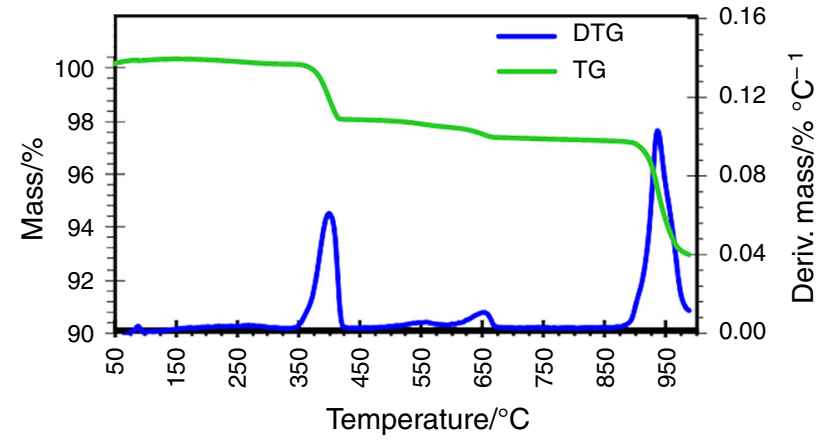

Fig. 2 TG and DTG curves for fly ash-cement mixture containing $\mathrm{Na}_{2} \mathrm{SO}_{4}$ and $\mathrm{Ca}(\mathrm{OH})_{2}$ (before addition of water)

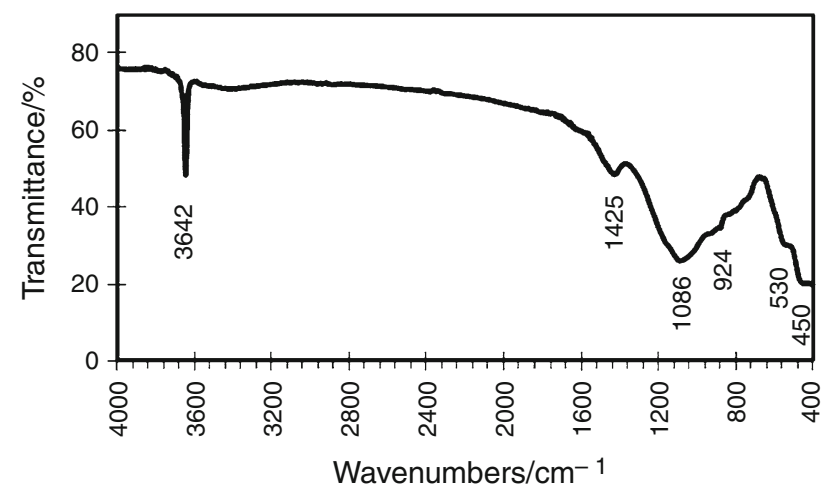

Fig. 3 IR spectra for fly ash-cement mixture containing $\mathrm{Na}_{2} \mathrm{SO}_{4}$ and $\mathrm{Ca}(\mathrm{OH})_{2}$ (before addition of water)
- calorimetric measurements-BMR calorimeter constructed at the Institute of Physical Chemistry, Polish Academy of Sciences, was used, and the results were calculated using computer software [24],

- thermogravimetry-SDT 2960 Thermoanalyzer (TA Instruments) was used, heating rate was $10^{\circ} \mathrm{C} \mathrm{min}^{-1}$, nitrogen atmosphere, and the mass of sample was 15-25 mg,

- infrared spectroscopy-FTIR spectrophotometer Genesis II (Mattson) was used, and the samples were prepared as $\mathrm{KBr}$ pellets,

- X-ray diffraction-Bruker D8 Advance diffractometer, $\mathrm{Cu}-\mathrm{K} \alpha$ radiation, was used

- SEM/EDS analysis-scanning electron microscope JEOL with an X-ray microanalyzer EDS was used.

\section{Results and discussion}

\section{Early hydration/activation periods}

Results of calorimetric measurements (Fig. 5) present kinetics of heat evolution for hydrating pastes. It is a known fact that the course of calorimetric curve and the amount of heat released are strictly associated with chemical processes taking place in the paste and, consequently, with some properties of binder [16, 25, 26]. Thus, influence of fly ash on binder reactivity and properties can be estimated. Delay of hydration, slow setting and hardening are especially visible when high amount of cement is substituted by low-calcium conventional fly ash [19]. Such phenomenon was confirmed once again in this work. Results for non-activated paste containing $80 \%$ of fly ash in the mix (80FA/20PC) show as follows: long induction period lasting almost up to 8th hour of hydration, small intensity and elongated period related to precipitation of $\mathrm{C}-$ $\mathrm{S}-\mathrm{H}$-type product, relatively low total amount of heat released after $48 \mathrm{~h}$ (Fig. 5 line 1). Low reaction degree of the fly ash-cement composition results from the fact that fly ash (used in this work) is poor in calcium and has no self-cementing properties. Cement can activate it.
Fig. 4 X-ray diffraction pattern for fly ash-cement mixture containing $\mathrm{Na}_{2} \mathrm{SO}_{4}$ and $\mathrm{Ca}(\mathrm{OH})_{2}$ (before addition of water), $\mathrm{A}$-alite, $\mathrm{M}$-mullite, $\mathrm{N}-\mathrm{Na}_{2} \mathrm{SO}_{4}, \mathrm{Q}-$ quartz, $\mathrm{P}$ portlandite

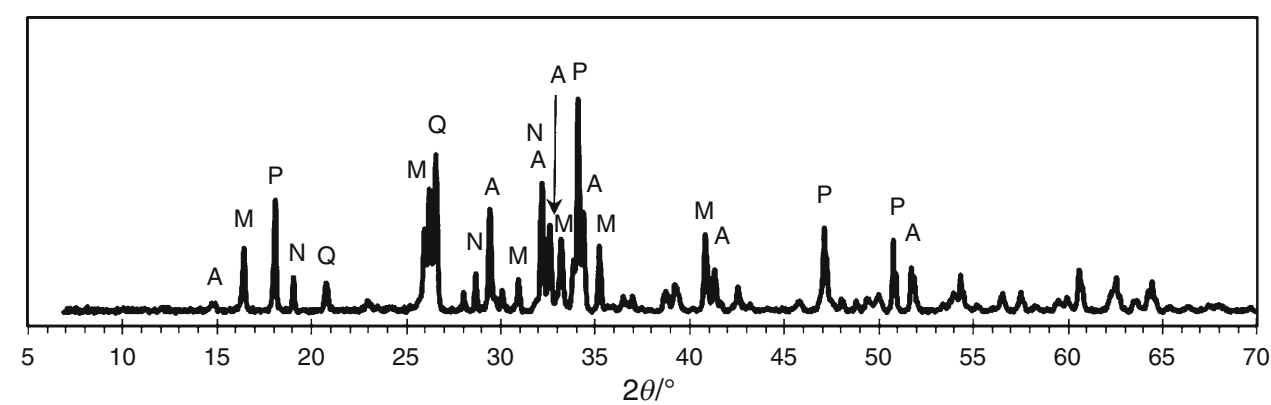


Table 1 Compositions of the investigated samples

\begin{tabular}{lllllll}
\hline \multirow{2}{*}{ Samples } & \multicolumn{6}{l}{ Quantity of the components/g } \\
\cline { 2 - 7 } & Portland cement (PC) & Fly ash (FA) & Sand (S) & $\mathrm{Na}_{2} \mathrm{SO}_{4}$ & $\mathrm{Ca}(\mathrm{OH})_{2}$ & Water \\
\hline 80FA/20PC (reference) & 20 & 80 & 0 & 0 & 0 & 50 \\
80FA/20PC-A & 20 & 80 & 0 & 4 & 10 & 50 \\
80S/20PC-A & 20 & 0 & 80 & 4 & 10 & 50 \\
80FA/20S-A & 0 & 80 & 20 & 4 & 10 & 50 \\
\hline
\end{tabular}
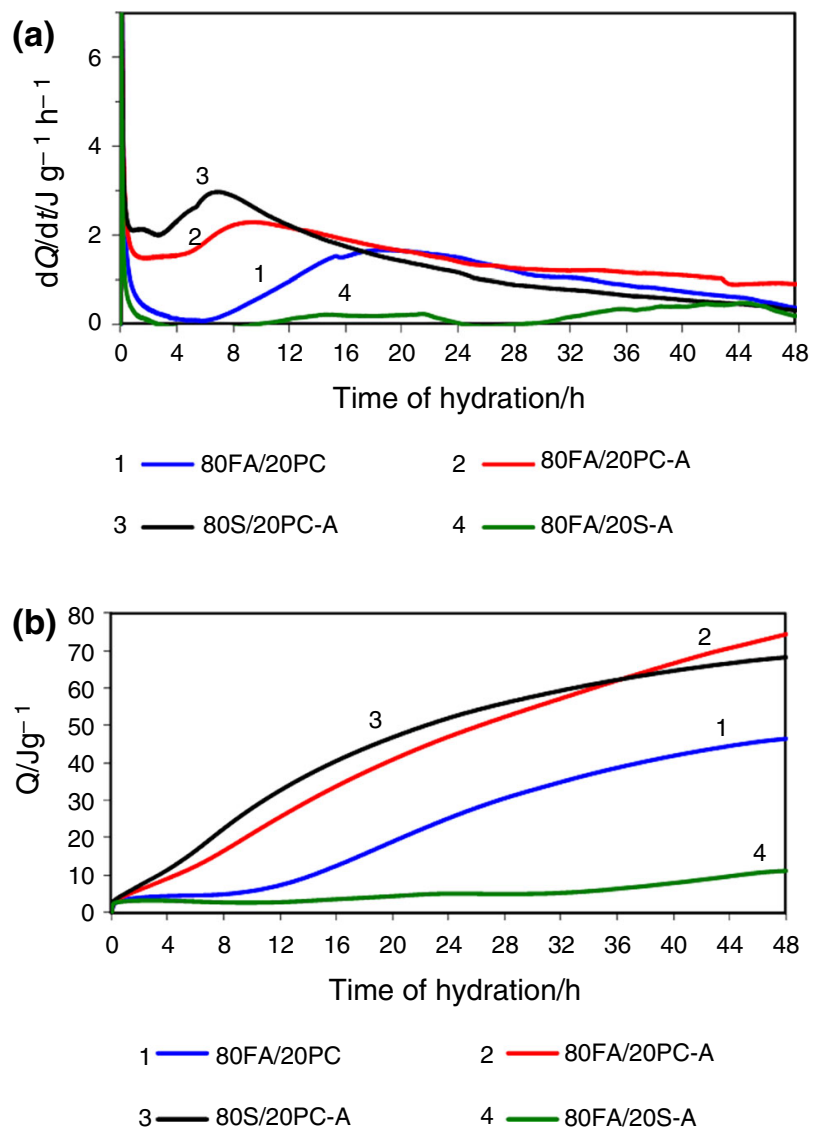

Fig. 5 Heat evolution curves (a) and total heat released (b) for investigated pastes

However, cement also needs some time to form $\mathrm{Ca}(\mathrm{OH})_{2}$ for pozzolanic reaction, and then fly ash needs time to react with this hydroxide. Thus, at early hydration period, setting and hardening depend mainly on cement hydration which is delayed by significant dilution effect of cement due to fly ash.

Introduction of $\mathrm{Na}_{2} \mathrm{SO}_{4}$ and $\mathrm{Ca}(\mathrm{OH})_{2}$ into fly ash-cement mixture (80FA/20PC-A) causes intensification of heat release rate, which indicates acceleration of early hydration processes (Fig. 5 line 2). Induction period is reduced (it ends about $5 \mathrm{~h}$ after the moment of water adding), and the next period of heat release is more intense compared to the result for reference (80FA/20PC). As a consequence, shorter initial setting time can be expected compared to non-activated sample. The total heat released after $48 \mathrm{~h}$ of measurement is also higher compared to result received for the non-activated sample. Thus, in general, tendency of changes of heat release observed previously [23] was confirmed in this work.

Comparison of the results registered for activated fly ash-cement paste (80FA/20PC-A) and those for samples containing sand instead of fly ash or cement (80S/20PC-A or $80 \mathrm{FA} / 20 \mathrm{~S}-\mathrm{A}$, respectively) disclosed that, in early period of hydration, activating effect is mainly caused by acceleration of cement hydration. However, some influence of chemical activators on fly ash reactivity is not excluded despite the short time of hydration. $\mathrm{Na}_{2} \mathrm{SO}_{4}$ is easily soluble in water and can react with $\mathrm{Ca}(\mathrm{OH})_{2}$ increasing $\mathrm{pH}$ of solution. Cement minerals can be more soluble in such conditions and undergo hydration earlier. Fly ash grains need more time and high $\mathrm{pH}$ to dissolve. It is visible that in the case of activated sample containing sand instead of fly ash (80S/20PC-A) activating effect is higher compared to result for fly ash-cement blend (80FA/20PC-A). However, starting from $36 \mathrm{~h}$ of hydration, total heat released for activated fly ash-cement paste is higher and increases continuously compared to result for sand-cement sample. It indicates the development of fly ash-cement activity. This conclusion is confirmed by calorimetric results registered for mixtures without cement (80FA/20S-A). In this case, fly ash slowly and with low intensity undergoes activation. The first stage of fly ash activity development takes place between 12 and $24 \mathrm{~h}$, while the second, slightly more intense, after $30 \mathrm{~h}$.

TG and DTG curves (Figs. 6 and 7) show a few stages of mass losses:

- up to about $380{ }^{\circ} \mathrm{C}$-dehydration of products such as: $\mathrm{C}-\mathrm{S}-\mathrm{H}$ phase, hydrated sulfoaluminates, hydrated aluminates, and, on very early hydration periods, also unreacted gypsum ( $\Delta \mathrm{m} 1$ - Fig. 8 );

- from about $380{ }^{\circ} \mathrm{C}$ to about $460{ }^{\circ} \mathrm{C}$-dehydroxylation of $\mathrm{Ca}(\mathrm{OH})_{2}(\Delta \mathrm{m} 2$ - Fig. 9);

- from about $600{ }^{\circ} \mathrm{C}$ to about $680{ }^{\circ} \mathrm{C}$-decomposition of carbonates;

- above $800{ }^{\circ} \mathrm{C}$-reduction of sulfates with non-burned carbon [27] (only for samples containing fly ash). 
Fig. 6 TG curves for

investigated pastes after

different periods of hydration

Fig. 7 DTG curves for

investigated pastes after

different periods of hydration
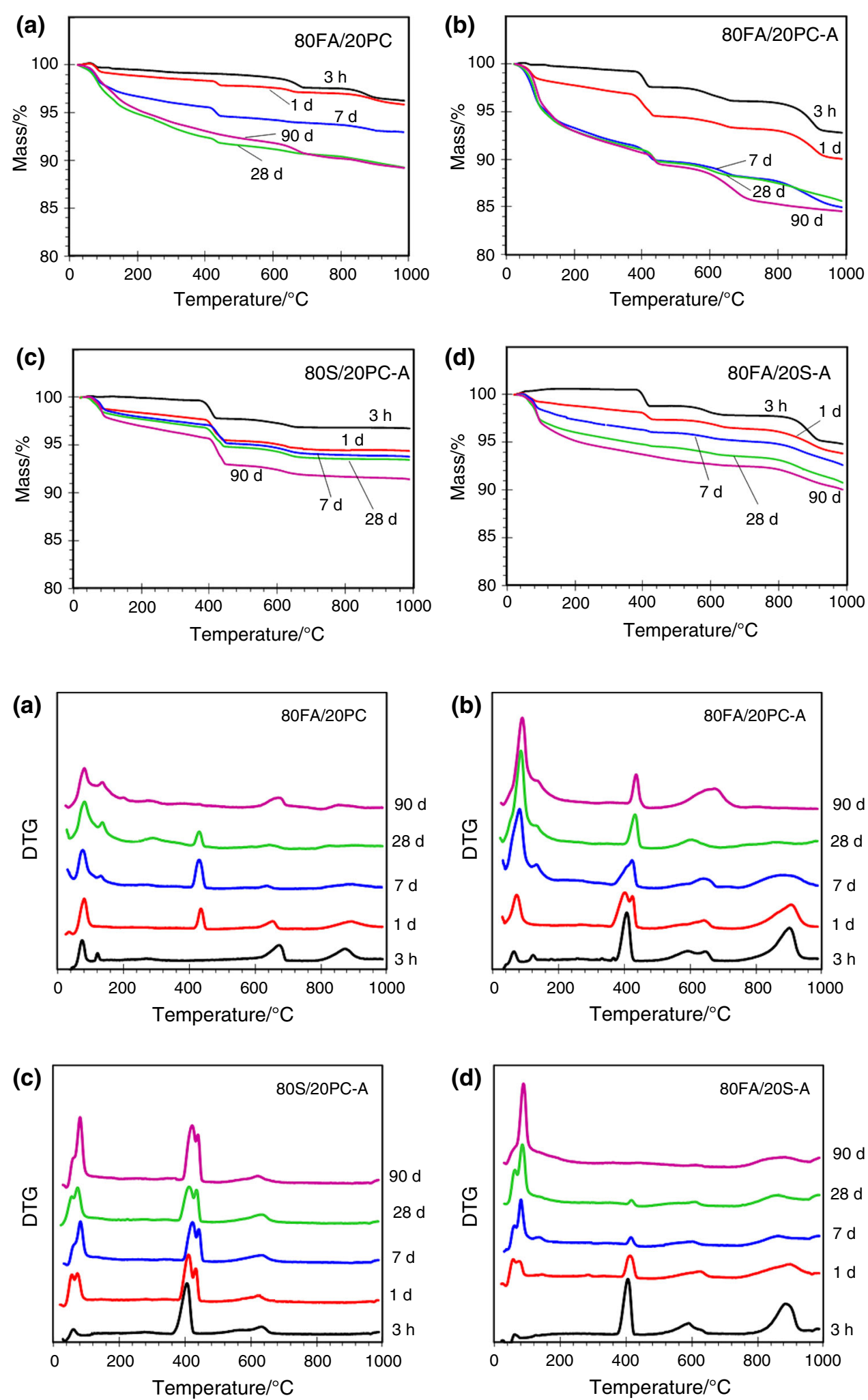

After early hydration period $(3 \mathrm{~h})$, the pastes bound a very low amount of water (estimated as $\Delta \mathrm{m} 1$, Fig. 8 ). Results registered for non-activated reference show that $\mathrm{Ca}(\mathrm{OH})_{2}$ is not precipitated at this early stage. Its presence as well as small increase in bound water is visible after 1st day. Two peaks on DTG (up to $150{ }^{\circ} \mathrm{C}$ ) after $3 \mathrm{~h}$ of hydration likely indicate the presence of small amount of 


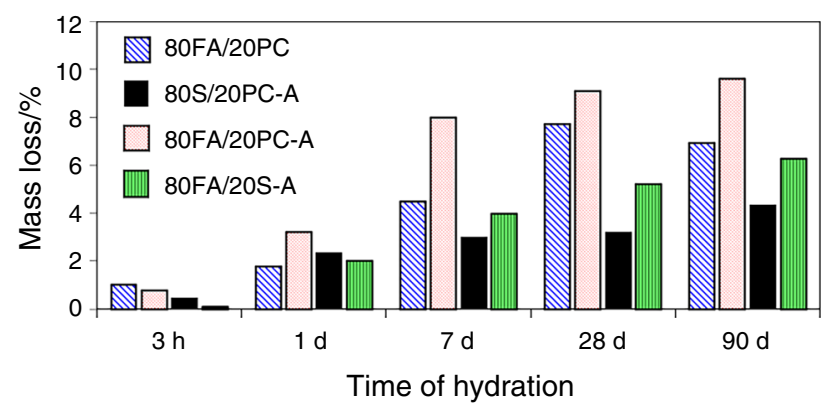

Fig. 8 Mass loss relating to water bound in hydrates $(\Delta \mathrm{m} 1)$

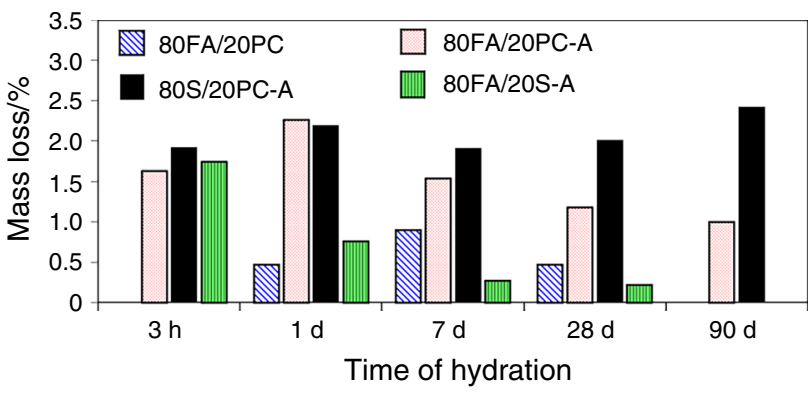

Fig. 9 Mass loss relating to decomposition of $\mathrm{Ca}(\mathrm{OH})_{2}(\Delta \mathrm{m} 2)$

gypsum which undergoes reaction during the next hydration periods (Fig. 7a).

The courses of TG/DTG curves (Figs. 6, 7) of activated mixtures after $3 \mathrm{~h}$ of hydration are similar to those obtained for non-activated one (80FA/20PC). The obvious difference is the pronounced effect of dehydroxylation of $\mathrm{Ca}(\mathrm{OH})_{2}$ which was introduced as an activator (on DTG, clear peak with an extreme at about $400{ }^{\circ} \mathrm{C}$ is visible for all activated samples). Because $\mathrm{Na}_{2} \mathrm{SO}_{4}$ is the second component of the activating mixture, TG/DTG curves for samples 80FA/20PC-A and 80FA/20S-A (Figs. 6b, d, 7b, d) exhibit more clear mass loss above $800{ }^{\circ} \mathrm{C}$ compared to result for non-activated reference. This effect is not visible for activated sample composed without fly ash (80S/20PCA) as this blend does not contain the carbon necessary for high-temperature reduction of sulfate.

On the 1st day of hydration, DTG curves registered for samples containing cement and chemical activators (Fig. 7b, c), i.e., 80FA/20PC-A and 80S/20PC-A, show untypical shape from about $360{ }^{\circ} \mathrm{C}$ to $460{ }^{\circ} \mathrm{C}$. Two peaks are visible at this temperature range. $\mathrm{Ca}(\mathrm{OH})_{2}$ from cement hydration appears (DTG peaks with extreme at about $430{ }^{\circ} \mathrm{C}$ visible for all samples containing cement). The results evidence that $\mathrm{Ca}(\mathrm{OH})_{2}$, which precipitated during cement hydration, has different morphology and, resulting from this, different thermal stability compared to $\mathrm{Ca}(\mathrm{OH})_{2}$ which was introduced as an activator. TG results show that mass loss resulting from dehydration of hydrated silicate, aluminate and sulfoaluminate phases $(\Delta \mathrm{m} 1)$ is the largest for activated fly ash-cement paste 80FA/20PC-A. Thus, this composition bound the greatest amount of water during $24 \mathrm{~h}$ of hydration.

TG and DTG curves for activated sample without cement (80FA/20S-A) exhibit significant reduction in the effect of decomposition of $\mathrm{Ca}(\mathrm{OH})_{2}$. Such results indicate that $\mathrm{Ca}(\mathrm{OH})_{2}$ quickly undergoes reaction in the system (reaction of $\mathrm{Ca}(\mathrm{OH})_{2}$ with $\mathrm{Na}_{2} \mathrm{SO}_{4}$ and start of pozzolanic reaction). Thus, conclusions based on the results of calorimetric measurements regarding the development of fly ash activity in the presence of chemical activators were confirmed.

For most samples, IR spectra (Fig. 10) after $3 \mathrm{~h}$ are similar (sample 80S/20PC-A is an exception, because of the absence of fly ash in its composition) and confirm low reaction degree. Intense and broad band with an extreme at about $1100 \mathrm{~cm}^{-1}$ is the main band of fly ash (asymmetric stretching vibrations of $\mathrm{Si}(\mathrm{Al})-\mathrm{O}$ bonds [28] in silica and aluminosilicate phases such as quartz, mullite and amorphous silica (overlapped bands)). The effects at about $545 \mathrm{~cm}^{-1}$ and about $450 \mathrm{~cm}^{-1}$ also come from the presence of fly ash in the mixture. The bands with extremes at $3420-3440$ and $1620-1650 \mathrm{~cm}^{-1}$ are related to the presence of water (stretching and bending vibrations of $\mathrm{H}-\mathrm{O}-$ $\mathrm{H}$ ), while bands at about 1420 and $875 \mathrm{~cm}^{-1}$ indicate the presence of carbonates. Some new bands for activated blends (Fig. 10b-d), compared to IR spectra for reference mixture (Fig. 10a), are associated with the presence of additional amounts of sulfate compound and $\mathrm{Ca}(\mathrm{OH})_{2}$. There is an intense sharp band at $3643 \mathrm{~cm}^{-1}$ related to vibrations of $\mathrm{OH}$ in $\mathrm{Ca}(\mathrm{OH})_{2}$. The main band related to $\mathrm{SO}_{4}^{2-}$ vibrations overlaps with the most intense band of fly ash and sand as it is placed at about $1100 \mathrm{~cm}^{-1}$. Sharp band at $617 \mathrm{~cm}^{-1}$ is connected with the presence of sulfates.

IR spectra collected after 1st day show that during this short time of hydration the first portions of hydrated products were precipitated and activating processes also started. In the case of activated fly ash-cement paste (80FA/20PC-A, Fig. 10b), the band at $1105 \mathrm{~cm}^{-1}$ and a shoulder at lower wavenumbers (about $1035 \mathrm{~cm}^{-1}$ ) are separated. It confirms transformations in aluminosilicate structure of fly ash. Similar effects were observed for sample without cement (80FA/20S-A, Fig. 10d). Moreover, significantly lower intensity of the $\mathrm{Ca}(\mathrm{OH})_{2}$ band confirms that this component undergoes reaction with the formation of new products. Precipitation of ettringite is not excluded as the bands typical for this product have similar position as the sulfates and some bands of fly ash. Thus, the effects overlap, for example the main intense band for ettringite is located at about $1120 \mathrm{~cm}^{-1}$ [29], another band at $620 \mathrm{~cm}^{-1}$ [30]. Presence of this component may be confirmed by X-ray diffraction results presented in Fig. 11 
(a) $80 \mathrm{FA} / 20 \mathrm{PC}$
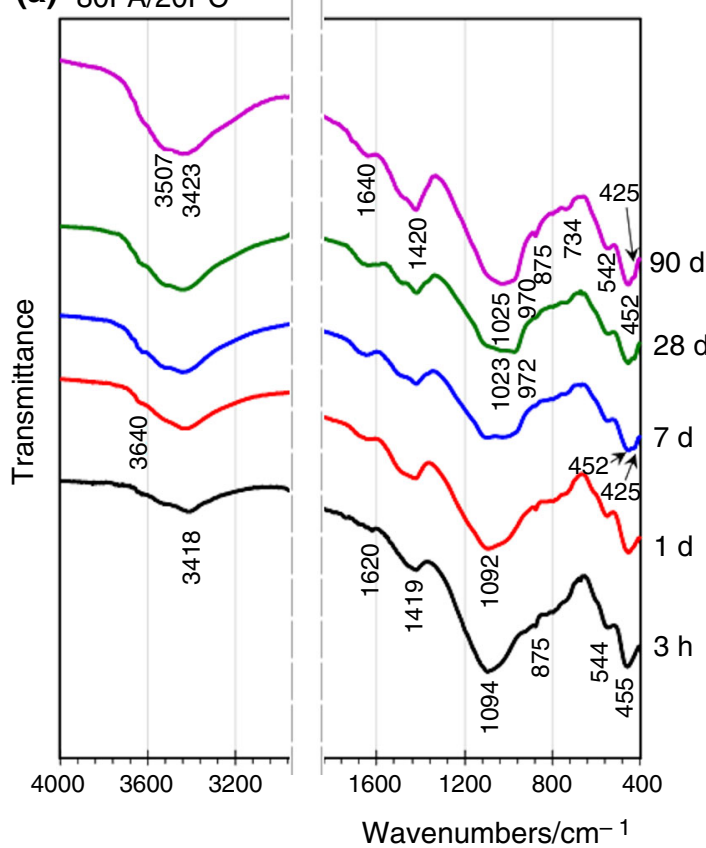

(c) $80 \mathrm{~S} / 20 \mathrm{PC}-\mathrm{A}$

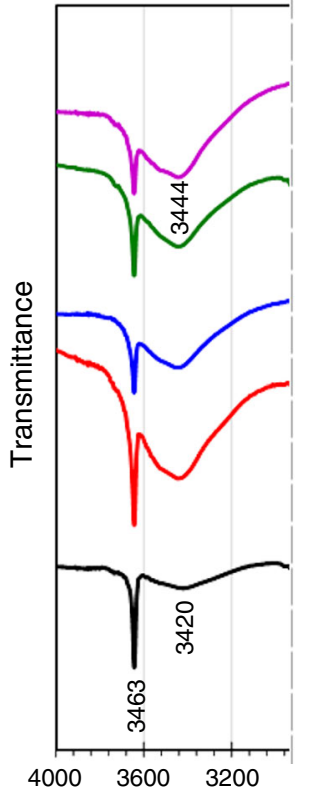

(b)
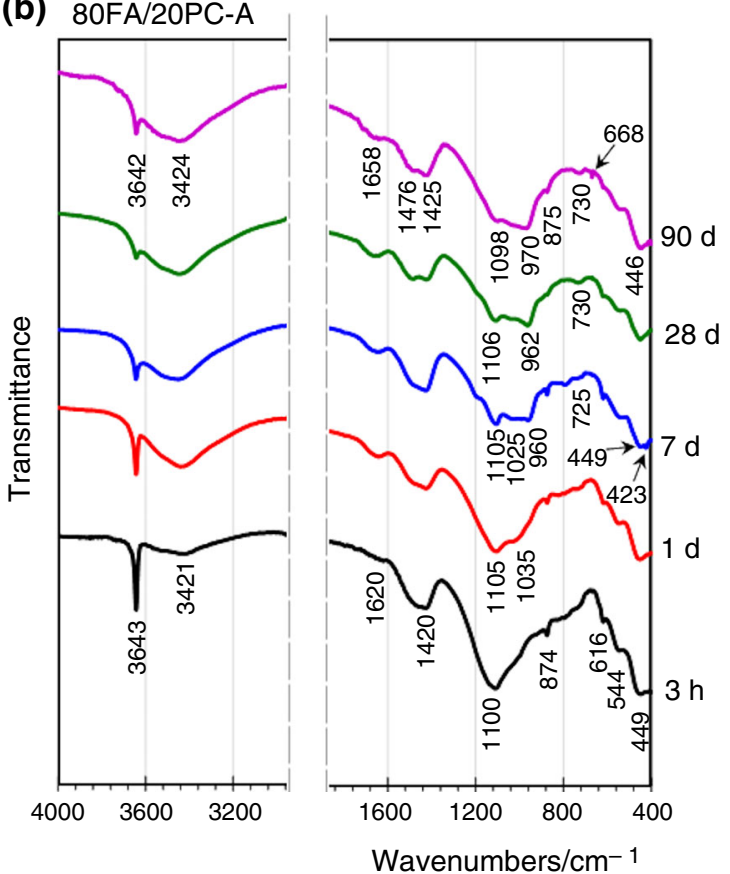

(d) $80 \mathrm{FA} / 20 \mathrm{~S}-\mathrm{A}$
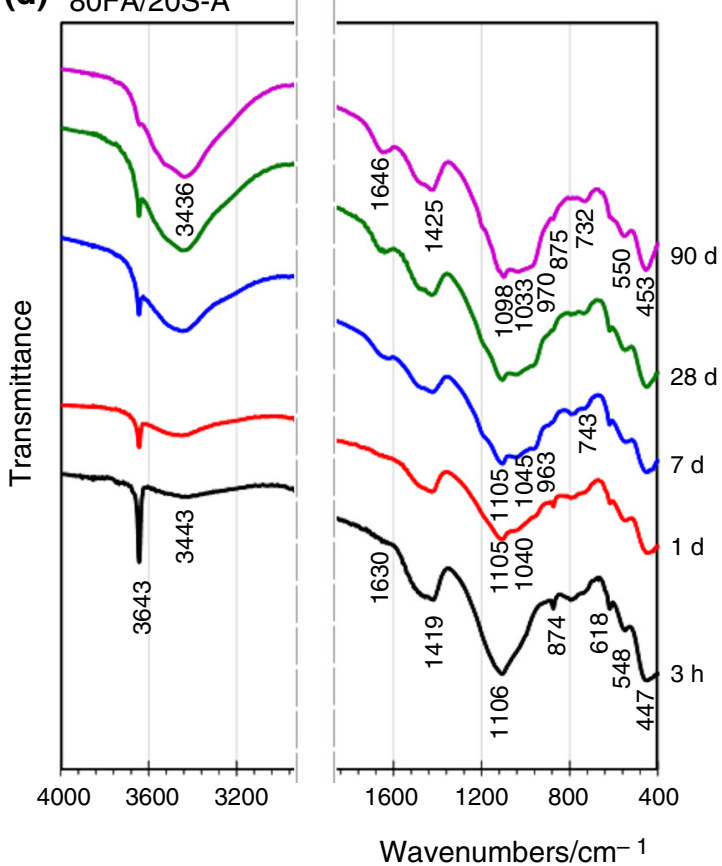

Fig. 10 IR spectra for investigated pastes after different periods of hydration

(very low intensity peaks for ettringite are visible for activated blend). Hydration/activation products formed at this early hydration period are amorphous. X-ray diffraction pattern shows the presence of a few crystalline components of fly ash-cement mix: quartz, mullite (from fly ash), calcite, calcium silicate $\mathrm{C}_{3} \mathrm{~S}$ (from cement) as well as effects related to activators $\left(\mathrm{Ca}(\mathrm{OH})_{2}, \mathrm{Na}_{2} \mathrm{SO}_{4}\right)$.
For comparison, in the case of non-activated blend, FTIR spectrum collected after 1st day has almost the same shape as spectrum after $3 \mathrm{~h}$. (Only insignificant broadening of the main fly ash band toward lower wavenumbers was observed.) Thus, conclusions presented above, based on calorimetric and thermogravimetric measurements, were confirmed. Chemical activators influence fly ash grains and 
Fig. 11 X-ray diffraction patterns for investigated pastes after 1st and 28th day of hydration, E-ettringite, $\mathrm{M}$ mullite, Q- quartz, $\mathrm{P}$ portlandite, $\mathrm{A}$-alite, $\mathrm{N}$ $\mathrm{Na}_{2} \mathrm{SO}_{4}, \mathrm{Cc}-\mathrm{CaCO}_{3}$
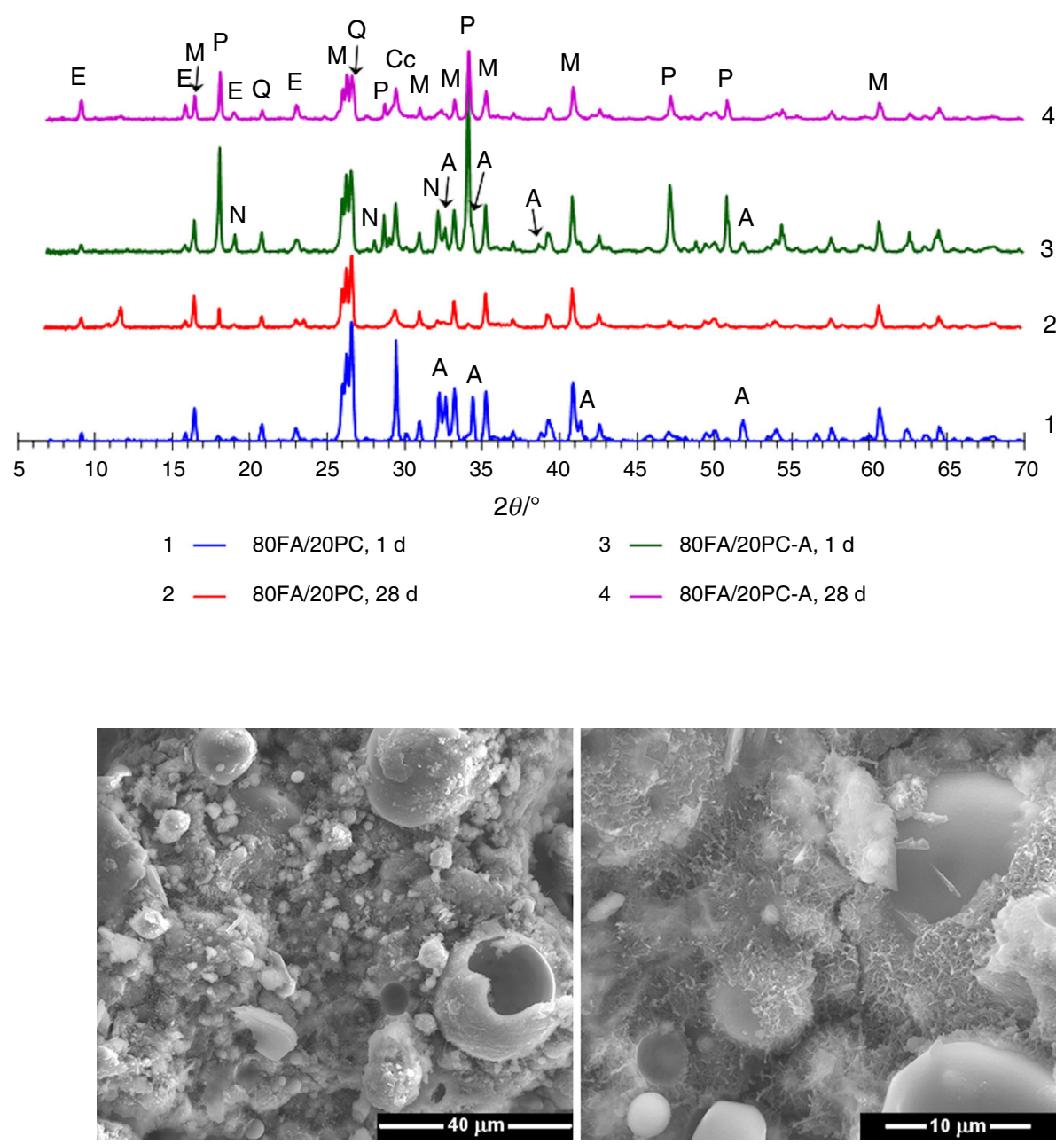

Fig. 12 Exemplary SEM images of microstructure of activated fly ash-cement paste (28th day of hydration) stimulate their reactivity just after several hours after addition of water.

IR spectra collected for mixture in which fly ash was replaced by sand (80S/20PC-A, Fig. 10c) show influence of chemical activators on cement hydration. Intense bands at $1112 \mathrm{~cm}^{-1}$ and about $620 \mathrm{~cm}^{-1}$ result probably from ettringite. Bands characteristic for silicates of portland cement change position. Moreover, new band at $668 \mathrm{~cm}^{-1}$ appears. It may confirm the formation of $\mathrm{C}-\mathrm{S}-\mathrm{H}$-type products [31].

\section{Later hydration/activation periods}

During the next days of hydration, fly ash develops its activity further and cement undergoes further hydration. As a result, the amount of bound water (presented as the mass loss $\Delta \mathrm{m} 1$, Fig. 8) increases with time. In the case of nonactivated reference paste $(80 \mathrm{FA} / 20 \mathrm{PC}), \mathrm{Ca}(\mathrm{OH})_{2}$ content rises till 7th day which confirms that hydration of cement predominates over pozzolanic reaction. After the 7th day, amount of $\mathrm{Ca}(\mathrm{OH})_{2}$ decreases (gradual reduction in mass loss at $410-460{ }^{\circ} \mathrm{C}$ over time, Fig. 9) ${ }^{2}$ and it is completely invisible after the 90th day. It affirms that pozzolanic activity in non-activated fly ash-cement blend develops after 7 days of hydration. Thus, previous results [19] obtained for fly ash-cement mixture were confirmed. Changes of the DTG shape (Fig. 7a) at temperature range up to $200{ }^{\circ} \mathrm{C}$ indicate that $\mathrm{C}-\mathrm{S}-\mathrm{H}$ is the main product of reference paste on early days of hydration, while, starting from 7th day, hydrated aluminates and aluminosilicates are also present. They are visible by the presence of DTG peak at about $140{ }^{\circ} \mathrm{C}$. A broad peak of small intensity at about $300{ }^{\circ} \mathrm{C}$ is also observed. Intensities of these effects increase with time starting from 7 th day of hydration.

Chemically activated fly ash-cement paste (80FA/20PCA), contrary to the results for reference mix, shows earlier development of reactivity (between 1 st and 7 th day). In the case of this sample, the amount of $\mathrm{Ca}(\mathrm{OH})_{2}$ rises till 1st day of hydration. Then, between 1st and 7th day, it starts to

\footnotetext{
2 The amount of $\mathrm{Ca}(\mathrm{OH})_{2}$ in the sample is proportional to mass loss related to decomposition of $\mathrm{Ca}(\mathrm{OH})_{2}$.
} 

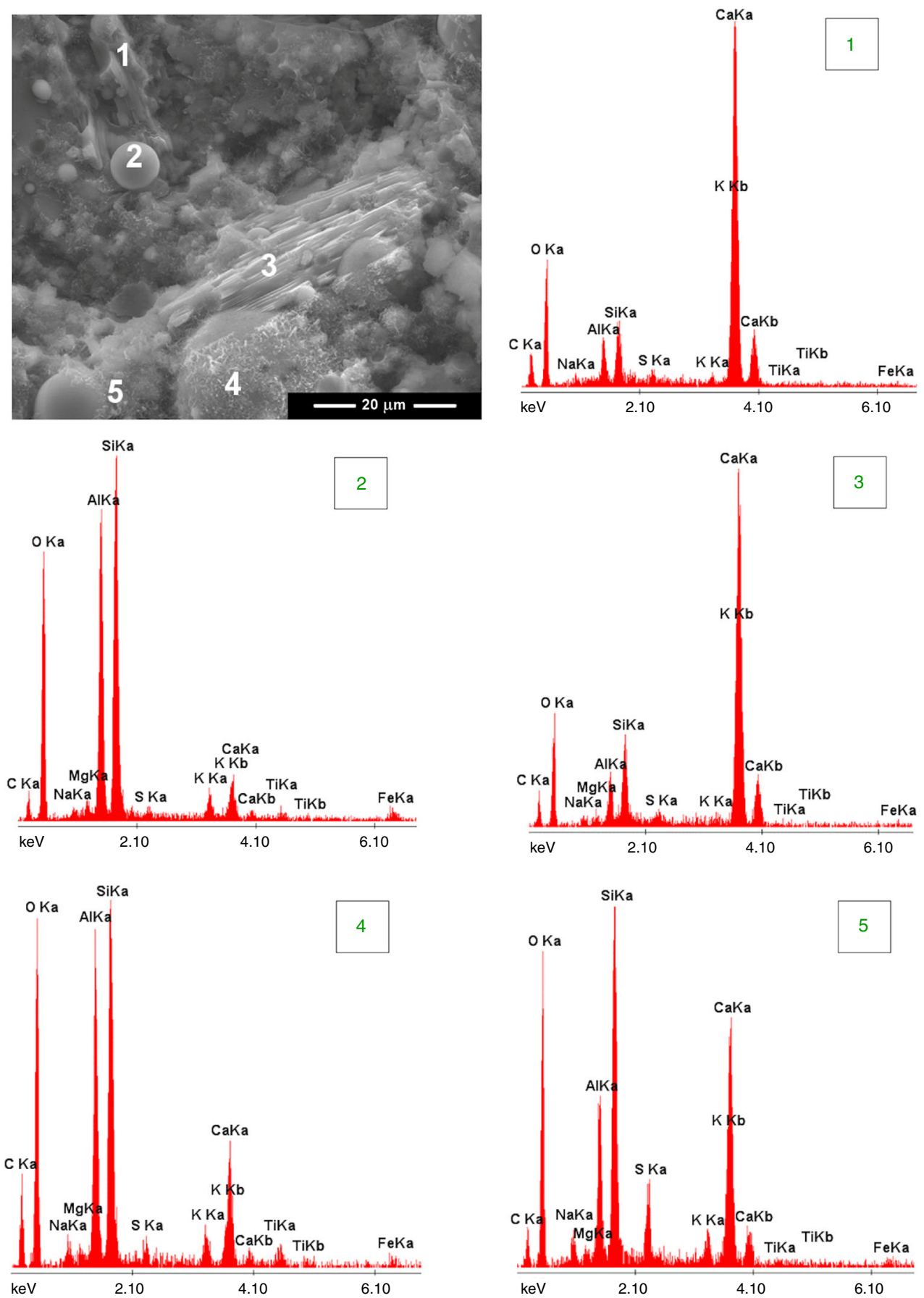

Fig. 13 Exemplary SEM image of microstructure of activated fly ash-cement paste (28th day of hydration) and EDS analysis of selected points $(1-5)$

reduce, probably partially as a result of reaction with $\mathrm{Na}_{2} \mathrm{SO}_{4}$ (in early periods) and mainly in pozzolanic reaction (in the following days). The amount of bound water for this mixture is the highest, compared to all investigated blends, through all days of investigation. Larger amount of water was bound between 1st and 7th day. After this time, the amount of water increases only slightly. The DTG curve indicates that
$\mathrm{Ca}(\mathrm{OH})_{2}$, introduced into fly ash-cement mixture as an activator, reacts faster than $\mathrm{Ca}(\mathrm{OH})_{2}$ which precipitated during cement hydration. The effect visible on DTG, responsible for decomposition of introduced $\mathrm{Ca}(\mathrm{OH})_{2}$, disappears till 28th day (Fig. 7b). On 90th day, the presence of $\mathrm{Ca}(\mathrm{OH})_{2}$ (product of hydration) was still visible. It can take part in pozzolanic reaction and form additional binding 
products of $\mathrm{C}-\mathrm{S}-\mathrm{H}$ and $\mathrm{C}-\mathrm{A}-\mathrm{S}-\mathrm{H}$ type in later days. The effect of mass loss over $800{ }^{\circ} \mathrm{C}$ also gradually disappears. It shows that sulfates are bound into other products. (Probably, they are partially incorporated into $\mathrm{C}-\mathrm{S}-\mathrm{H}$ phase.) Shapes of DTG curves at temperature range up to $200{ }^{\circ} \mathrm{C}$ indicate that $\mathrm{C}-\mathrm{S}-\mathrm{H}$ phase and ettringite are the main products of reactions. Small effect at about $120{ }^{\circ} \mathrm{C}$ can indicate formation of the Afm phase and/or hydrated aluminosilicate products. X-ray diffraction patterns (Fig. 11) confirm the presence of ettringite after 28 days of hydration, which in the form of needles is also visible in SEM images (Figs. 12, 13). Ettringite may be formed as a result of the presence of cement in the mixtures and introduction of gypsum along with it. However, the amount of gypsum from cement is very low. Adding chemical activators, i.e., $\mathrm{Ca}(\mathrm{OH})_{2}$ and $\mathrm{Na}_{2} \mathrm{SO}_{4}$, favors creation of sulfoaluminates. These activators can react with each other in an aqueous environment forming easily soluble $\mathrm{NaOH}$ (which increases $\mathrm{pH}$ of solution and promotes dissolution of aluminosilicate grains of fly ash) and gypsum which precipitates [10, 12, 14, 18]. According to information given in $[10,12]$, gypsum created in this way is probably metastable and can be quickly consumed.

TG/DTG results show that the form of $\mathrm{Ca}(\mathrm{OH})_{2}$ which has lower thermal stability can be relatively fast bound in other compounds. It is especially visible in the case of sample in which the only source of $\mathrm{Ca}(\mathrm{OH})_{2}$ is the one introduced as an activator (80FA/20S-A). On the other hand, blend containing sand (instead of fly ash) and cement, 80S/20PC-A, shows the presence of both forms of $\mathrm{Ca}(\mathrm{OH})_{2}$ without its reduction over time. This is because the composition does not contain pozzolan which can react with $\mathrm{Ca}(\mathrm{OH})_{2}$. Comparison of the TG/DTG results obtained for activated fly ash-cement pastes (Figs. 6b and 7b) with those for samples without cement (Figs. 6d and $7 d)$ show that introduced $\mathrm{Ca}(\mathrm{OH})_{2}$ was bound up to 90th day of hydration and $\mathrm{C}-\mathrm{S}-\mathrm{H}$ and ettringite are the main products of hydration/activation processes. In the case of 80FA/20S-A sample, hydrated aluminates are probably not formed or only in a small degree, similarly as in the case of sample without fly ash (Figs. 6c and 7c).

Transformation of silica and aluminosilicate components of fly ash over time toward new silicate and aluminosilicate products is also confirmed in IR spectra (Fig. 10). In the case of non-activated fly ash-cement paste (80FA/20PC, Fig. 10a), the main fly ash band widens and gradually forms a new extreme at lower wavenumbers. The extreme visible at about $970 \mathrm{~cm}^{-1}$ on 28 th day indicates formation of $\mathrm{C}-\mathrm{S}-\mathrm{H}$ phase. Moreover, a new band at about $425 \mathrm{~cm}^{-1}$ appears on $7 \mathrm{th}$ day of hydration. For activated fly ash-cement blend (80FA/20PC-A, Fig. 10b), the bands confirming formation of new aluminosilicate phases are visible earlier and more clearly. For example, on 28th day of hydration the band at $1025 \mathrm{~cm}^{-1}$, clear and intense band at $962 \mathrm{~cm}^{-1}$ and $730 \mathrm{~cm}^{-1}$ are visible.

Figures 12 and 13 present microstructure of activated fly ash-cement binder after 28th day of hydration. There are visible products of hydration/activation formed around grains of fly ash. Figure 13 shows different components which can be found in the microstructure: region enriched in calcium (points 1 and 3), non-reacted aluminosilicate fly ash grains (point 2), C-A-S-H product (point 4) and aluminosilicate product enriched in sulfur (point 5).

\section{Conclusions}

1. Chemical compounds, $\mathrm{Na}_{2} \mathrm{SO}_{4}$ and $\mathrm{Ca}(\mathrm{OH})_{2}$, can activate fly ash-cement mixture. It is evidenced, compared to non-activated fly ash-cement blend, by: shortening of induction period and intensification of period related to precipitation of $\mathrm{C}-\mathrm{S}-\mathrm{H}$, increasing total heat released after $48 \mathrm{~h}$ of hydration, higher amount of bound water, reduction of $\mathrm{Ca}(\mathrm{OH})_{2}$ and quicker precipitation of hydrated products resulting from faster development of pozzolanic activity.

2. Ettringite is one of the hydration products, formed in higher amount in chemically activated mix as an effect of introduction of sulfate.

3. Chemical activators accelerate cement hydration and enhance reactivity of fly ash grains. In activated fly ash-cement binder, synergic effect takes place.

4. In early hydration hours, the presence of cement is mainly responsible for activating effect of fly ashcement mixture. During $24 \mathrm{~h}$ of hydration, fly ash starts to react.

5. Two kinds of $\mathrm{Ca}(\mathrm{OH})_{2}$ can be present in activated fly ash-cement system: hydroxide introduced as component of activating mixture and the one precipitated as cement hydration product.

6. The knowledge about kinetics of chemical and physical processes of hydration/activation and products that are formed is key factor to develop new more ecological binders which could replace cement in the future. Results of investigation on other ways of activation of such systems (i.e., very high volume fly ash mixtures) will be discussed in next works.

Open Access This article is distributed under the terms of the Creative Commons Attribution 4.0 International License (http://creative commons.org/licenses/by/4.0/), which permits unrestricted use, distribution, and reproduction in any medium, provided you give appropriate credit to the original author(s) and the source, provide a link to the Creative Commons license, and indicate if changes were made. 


\section{References}

1. Gartner E, Hirao H. A review of alternative approaches to the reduction of $\mathrm{CO}_{2}$ emissions associated with the manufacture of the binder phase in concrete. Cem Concr Res. 2015;78:126-42.

2. Andrew RM. Global $\mathrm{CO}_{2}$ emissions from cement production. Earth Syst Sci Data. 2018;10:195-217.

3. EN 197-1. Cement-part 1: composition, specifications and conformity criteria for common cements. 2012.

4. Aydin E, Şahan Arel H. Characterization of high-volume fly-ash cement pastes for sustainable construction applications. Constr Build Mater. 2017;157:97-107.

5. Dung NT, Chang T-P, Chen C-T, Yang T-R. Cementitious properties and microstructure of an innovative slag eco-binder. Mater Struct. 2016;49:2009-24.

6. Kledyński Z, Machowska A, Pacewska B, Wilińska I. Investigation of hydration products of fly ash-slag pastes. J Therm Anal Calorim. 2017;130:351-63.

7. Qu B, Martin A, Pastor JY, Palomo A, Fernández-Jiménez A. Characterisation of pre-industrial hybrid cement and effect of precuring temperature. Cem Concr Compos. 2016;73:281-8.

8. Bondar D, Coakley E. Effect of grinding on early age performance of high volume fly ash ternary blended pastes with CKD \& OPC. Constr Build Mater. 2017;136:153-63.

9. Angulo-Ramírez DE, de Gutiérrez RM, Puertas F. Alkali-activated Portland blast-furnace slag cement: mechanical properties and hydration. Constr Build Mater. 2017;140:119-28.

10. Donatello S, Fernández-Jiménez A, Palomo A. Very high volume fly ash cements. Early age hydration study using $\mathrm{Na}_{2} \mathrm{SO}_{4}$ as an activator. J Am Ceram Soc. 2013;96:900-6.

11. Huang C-H, Lin S-K, Chang C-S, Chen H-J. Mix proportions and mechanical properties of concrete containing very high-volume of Class F fly ash. Constr Build Mater. 2013;46:71-8.

12. Donatello S, Maltseva O, Fernández-Jiménez A, Palomo A. The early age hydration reactions of a hybrid cement containing a very high content of coal bottom ash. J Am Ceram Soc. 2014;97:929-37.

13. Alahrache S, Winnefeld F, Champenois J-B, Hesselbarth F, Lothenbach B. Chemical activation of hybrid binders based on siliceous fly ash and Portland cement. Cem Concr Compos. 2016;66:10-23.

14. Garcia-Lodeiro I, Donatello S, Fernández-Jiménez A, Palomo A. Hydration of hybrid alkaline cement containing a very large proportion of fly ash: a descriptive model. Materials. 2016;9:605.

15. Garcia-Lodeiro I, Fernández-Jiménez A, Palomo A. Hydration kinetics in hybrid binders: early reaction stages. Cem Concr Compos. 2013;39:82-92.

16. Kurdowski W. Chemia cementu i betonu. Kraków: Stowarzyszenie Producentów Cementu; 2010 (in Polish).

17. Wilińska I, Pacewska B. Influence of selected activating methods on hydration processes of mixtures containing high and very high amount of fly ash-a review. J Therm Anal Calorim. 2018;133:823-43.
18. Martauz P, Janotka I, Strigáč J, Bačuvčik M. Fundamental properties of industrial hybrid cement: utilization in ready-mixed concretes and shrinkage-reducing applications. Mater Constr. 2016;66:1-14.

19. Wilińska I, Pacewska B. Calorimetric and thermal analysis studies on the influence of waste aluminosilicate catalyst on the hydration of fly ash-cement paste. J Therm Anal Calorim. 2014;116:689-97.

20. Pacewska B, Wilińska I. Comparative investigations of influence of chemical admixtures on pozzolanic and hydraulic activities of fly ash with the use of thermal analysis and infrared spectroscopy. J Therm Anal Calorim. 2015;120:119-27.

21. Pacewska B, Wilińska I, Blonkowski G. Investigations of cement early hydration in the presence of chemically activated fly ash. Use of calorimetry and infrared absorption methods. J Therm Anal Calorim. 2008;93:769-76.

22. Pacewska B, Wilińska I. Hydration of cement composites containing large amount of waste materials. Procedia Eng. 2013;57:53-62.

23. Wilińska I, Pacewska B. Zastosowanie kalorymetrii we wstępnych badaniach aktywowanych mieszanek popiołowo-cementowych. Przem Chem. 2017;96:761-5 (in Polish).

24. Poznański J. Computer software for processing of data obtained from calorimeter, 2012.

25. Mostafa NY, Brown PW. Heat of hydration of high reactive pozzolans in blended cements: isothermal conduction calorimetry. Thermochim Acta. 2005;435:162-7.

26. Bullard JW, Jennings HM, Livingston RA, Nonat A, Scherer GW, Schweitzer JS, Scrivener KL, Thomas JJ. Mechanisms of cement hydration. Cem Concr Res. 2011;41:1208-23.

27. van der Merwe EM, Strydom CA, Potgieter JH. Thermogravimetric analysis of the reaction between carbon and $\mathrm{CaSO}_{4} \cdot 2 \mathrm{H}_{2} \mathrm{O}$, gypsum and phosphogypsum in an inert atmosphere. Thermochim Acta. 1999;340-341:431-7.

28. Fernández-Jiménez A, Palomo A. Mid-infrared spectroscopic studies of alkali-activated fly ash structure. Microporous Mesoporous Mater. 2005;86:207-14.

29. Fernández-Carrasco L, Torrens-Martín D, Morales LM, Martínez-Ramírez S. Infrared spectroscopy in the analysis of building and construction materials. Infrared Spectrosc Mater Sci Eng Technol InTech. 2012;369-382. https://www.intechopen.com/ books/infrared-spectroscopy-materials-science-engineering-andtechnology/infrared-spectroscopy-of-cementitious-materials.

30. Yilmaz B, Olgun A. Studies on cement and mortar containing low-calcium fly ash, limestone, and dolomitic limestone. Cem Concr Comp. 2008;30:194-201.

31. Li X-G, Chen Q-B, Huang K-Z, Ma B-G, Wu B. Cementitious properties and hydration mechanism of circulating fluidized bed combustion (CFBC) desulfurization ashes. Constr Build Mater. 2012;36:182-7.

Publisher's Note Springer Nature remains neutral with regard to jurisdictional claims in published maps and institutional affiliations. 